\title{
Wind Speed Potential Analysis Based on Weibull Distribution
}

\author{
E. Dokur, and M. Kurban
}

\begin{abstract}
Weibull probability density function used to determine the wind energy potential commonly. In this paper, wind energy potential of Bilecik region is analyzed statistically by using the Turkish State Meteorological Service's hourly wind speed data between 2010-2014 measured in Bilecik meteorological station. It is used the two- parameter Weibull to determine wind energy potential of the region. The parameters of the Weibull distributions used for finding the estimation of average speed, standard deviation, and power density is found by using the Maximum likelihood method. All analysis is carried out by Matrix Laboratory (MATLAB) programming language. Monthly and yearly wind speeds are modeled by Weibull distribution statistically. Accuracy of the modeling is evaluated in terms of Root Mean Square Error (RMSE).
\end{abstract}

Index Terms - Weibull Distribution, Wind Speed, Energy.

\section{INTRODUCTION}

$\mathrm{G}$ LOBALLY fossil resources have very wide application area. The reason that fossil fuels used for meeting the energy need shall run short together with the fact that they are harmful for the environment leaded the path for a search of new energy sources worldwide and renewable energy sources have gained importance in this respect.

One of the renewable energy resources is wind energy. Actually wind energy which is the oldest source has been used since BC 2800 by humankind. Until recent year this energy has been used for water pumping and power generation in rural areas. Today it is used as an alternative source of energy production. Wind energy systems operate depend on wind regime, wind shaft position and size of power generation system $[1,2]$.

Wind energy conversion systems are chosen based on wind speed potential analysis of a region. Frequency distribution of wind speed can be displayed different distributions such as Gamma, lognormal, Rayleigh and Weibull. Two parameter Weibull distribution is used to model of many regions of the world wind speed in recent year. The reason of using this method is very good fit wind distribution [3].

E. Dokur, Electrical and Electronics Engineering Department, Bilecik S.E. University, Bilecik, Turkey, (e-mail: emrah.dokur@bilecik.edu.tr).

M. Kurban, Electrical and Electronics Engineering Department, Bilecik S.E. University, Bilecik, Turkey, (e-mail: mehmet.kurban@bilecik.edu.tr)
Two Weibull parameters are estimated using both the graphical and maximum likelihood methods. Genc et al [4]. Wind energy potential of Nigde region is studied statistically by using the Turkish State Meteorological Service's hourly wind speed data between 2008 and 2009 measured in Nigde meteorological station by Yildırım et al [5]. On the side, there is novel method about Weibull distribution in literature [6].

In this paper, wind energy potential is modelled based on two parameter Weibull distribution statistically for Bilecik ,city in Turkey, by using the Turkish State Meteorological Service's hourly wind speed data between 2010 and 2014 measured. Scale and shape parameters are determined by maximum likelihood method. Matlab (C) (Matrix Laboratory) software is used for all analyses. Performance criteria of model is shown that RMSE (Root Mean Square Error).

\section{WEIBULL DISTRIBUTION}

There are different methods for determining the wind speed distributions. In the literature, the two parameters Weibull distribution is often used in the statistical analysis of data. The Weibull distribution function is given by formula (1) :

$f(\mathrm{v})=\frac{k}{c}\left(\frac{v}{c}\right)^{k-1} e^{-\left(\frac{v}{c}\right)^{k}}$

Where $f(v)$ is the frequency or probability of occurrence of wind speed $\mathrm{V}, \mathrm{c}$ is the Weibull scale parameter with unit equals to the wind speed unit and $\mathrm{k}$ is the unitless Weibull shape parameter. The higher value of $c$ indicates that the wind speed is higher, while the value of $\mathrm{k}$ shows the wind stability. $k$ shape parameters are between 1.2 and 2.75 in the literature. The cumulative Weibull distribution function $F(V)$ gives the probability of the wind speed exceeding the value V. It is expressed by formula (2):

$\mathrm{F}(\mathrm{v})=1-e^{-\left(\frac{v}{c}\right)^{k}}$

Maximum frequency of wind speed is determined by formula (3):

$v_{\text {mod }}=c\left(1-\frac{1}{k}\right)^{1 / k}$

Maximum wind speed can be calculated formula (4) [7] : 
$v_{\text {maks }}=c\left(\frac{k+2}{k}\right)^{1 / k}$

Wind power is found commonly by formula (5) :

$P=\frac{1}{2} \rho A v^{3}$

Where $\rho\left(\mathrm{kg} / \mathrm{m}^{3}\right)$ is air density, A $\left(\mathrm{m}^{2}\right)$ is swept area. Mean power density for Weibull distribution is given by formula (6):

$P_{w}=\frac{1}{2} \rho c^{3} \Gamma\left(1+\frac{3}{k}\right)$

Where $\Gamma$ is gamma function. Here, taking into account, the density of the air at sea level, 1 atmosphere pressure and 16.6. Celsius degree $\rho_{0}=1.225 \mathrm{~kg} / \mathrm{m}^{3}$ value; the corrected air density in reference to the height of the sea level $\left(\mathrm{H}_{\mathrm{m}}\right)$ and other location information can be found according to formula (7) [8].

$\rho=\rho_{0}-1.194 .10^{-4} H_{m}$

As is seen that the most important input is wind speed data for determining of power potential. Wind direction is important for position of installation wind energy conversion systems.

\section{MAXIMUM LIKELIHOOD METHOD}

Several methods are available in order to determine the two parameters of Weibull distribution. One of these methods is maximum likelihood method that is proposed by Steven and Smulders [9]. Maximum likelihood method requires large scale numerical iterations. Shape parameter and scale parameter are calculated by formula (8) and formula (9):

$k=\left(\frac{\sum_{i=1}^{n} v_{i}^{k} \ln \left(\mathrm{v}_{i}\right)}{\sum_{i=1}^{n} v_{i}^{k}}-\frac{\sum_{i=1}^{n} \ln \left(\mathrm{v}_{i}\right)}{n}\right)^{-1}$

$c=\left(\frac{\sum_{i=1}^{n}\left(v_{i}\right)^{k}}{\sum_{i=1}^{n} v_{i}^{k}}\right)^{\frac{1}{k}}$

Where $\mathrm{v}_{\mathrm{i}}$ is wind speed and $\mathrm{n}$ is number of wind speeds.

Performance criteria of analysis is shown Root Mean Square Error (RMSE) by formula (10).
$R M S E=\sqrt{\frac{1}{n} \sum_{i=1}^{n}\left(\mathrm{y}_{i}-\mathrm{x}_{i}\right)^{2}}$

Where, $\mathrm{y}_{\mathrm{i}}$ is the actual wind speed probability value, $\mathrm{x}_{\mathrm{i}}$ is the probability value calculated from Weibull distribution and $n$ is the number of observations.

\section{WIND SPEED POTENTIAL ANALYSIS}

Future and available wind potential is very important to build of wind energy conversion system. For this reason estimation parameter results of distribution are studied monthly. Optimum model can be chosen according to performance criteria. In this paper, estimation of monthly and annual parameters for Bilecik region are implemented in table 1 by using hourly wind speed data between 2010 and 2014. The maximum likelihood method was used for determining Weibull parameters.

It can be seen from the Figure 1 that Weibull distribution function and cumulative distribution function of sample data, April 2010, was shown.
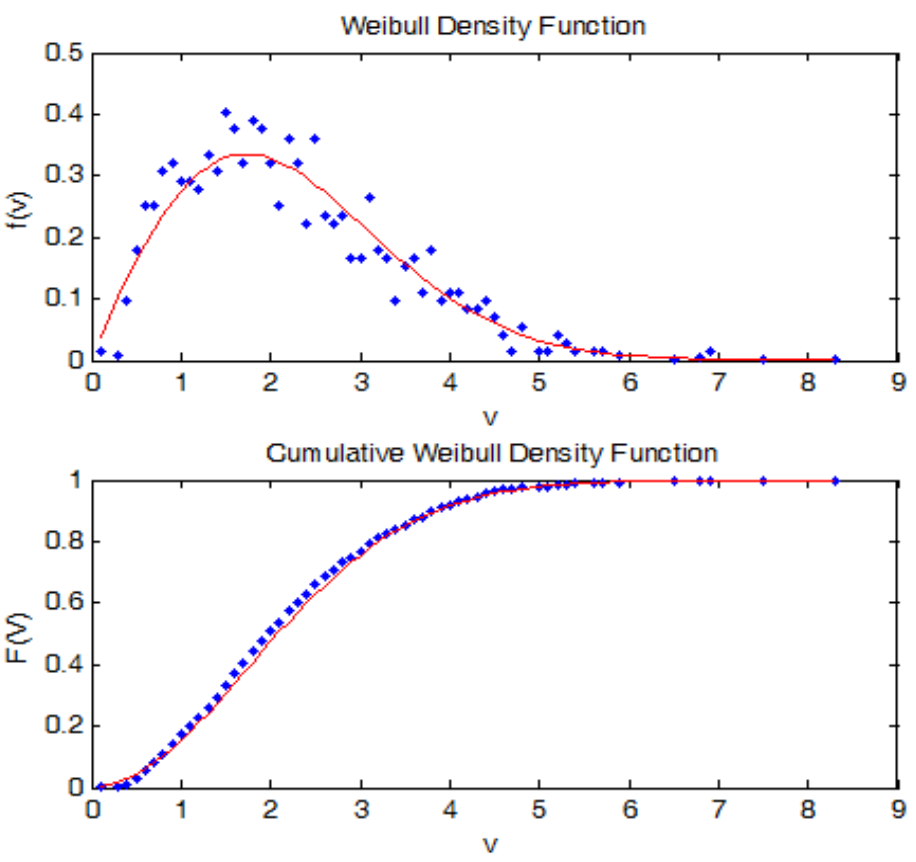

Fig.1. Probability density and cumulative probability density function for sample months 
TABLE 1

WEIBULL PARAMETERS AND ERROR VALUES

\begin{tabular}{|c|c|c|c|c|c|c|c|c|c|c|c|c|c|c|c|}
\hline \multirow[b]{2}{*}{ Months } & \multicolumn{3}{|c|}{2010} & \multicolumn{3}{|c|}{2011} & \multicolumn{3}{|c|}{2012} & \multicolumn{3}{|c|}{2013} & \multicolumn{3}{|c|}{2014} \\
\hline & $\mathbf{k}$ & c & RMSE & $\mathbf{k}$ & c & RMSE & $\mathbf{k}$ & c & RMSE & $\mathbf{k}$ & c & RMSE & $\mathbf{k}$ & c & RMSE \\
\hline January & 1.8139 & 2.4980 & 0.0254 & 2.0186 & 2.1777 & 0.0232 & 1.8901 & 2.4506 & 0.0367 & 2.2400 & 2.4860 & 0.0284 & 2.1885 & 2.0545 & 0.0328 \\
\hline February & 1.8435 & 2.4785 & 0.0250 & 2.0939 & 2.0817 & 0.0281 & 1.9126 & 3.1130 & 0.0338 & 2.1236 & 2.2914 & 0.0387 & 1.9435 & 1.8455 & 0.0406 \\
\hline March & 1.8592 & 2.4059 & 0.0228 & 1.8042 & 2.4342 & 0.0311 & 1.8626 & 2.2839 & 0.0304 & 2.0730 & 1.2524 & 0.0364 & 2.2748 & 2.1660 & 0.0261 \\
\hline April & 1.9416 & 2.5110 & 0.0172 & 1.7541 & 2.4472 & 0.0301 & 1.7668 & 2.6074 & 0.0318 & 2.3111 & 2.3331 & 0.0267 & 2.0241 & 2.0614 & 0.0320 \\
\hline May & 1.7574 & 2.3265 & 0.0292 & 2.0714 & 2.2945 & 0.0197 & 1.9938 & 2.1983 & 0.0317 & 1.9387 & 2.3502 & 0.0322 & 2.0202 & 2.0965 & 0.0258 \\
\hline June & 1.9759 & 2.5162 & 0.0267 & 2.1847 & 2.3154 & 0.0177 & 1.9064 & 2.4906 & 0.0287 & 1.9435 & 2.6441 & 0.0322 & 2.1401 & 2.3132 & 0.0294 \\
\hline July & 2.2358 & 2.9342 & 0.0158 & 2.1570 & 2.6608 & 0.0220 & 2.1363 & 2.9130 & 0.0231 & 2.3567 & 3.1580 & 0.0247 & 2.2348 & 2.5420 & 0.0301 \\
\hline August & 1.9625 & 2.7771 & 0.0177 & 2.2373 & 2.9908 & 0.0246 & 2.0782 & 2.8532 & 0.0287 & 2.1287 & 2.8553 & 0.0362 & 2.0093 & 2.5030 & 0.0324 \\
\hline September & 2.0343 & 2.4339 & 0.0204 & 2.2018 & 2.4763 & 0.0186 & 1.9479 & 2.3917 & 0.0280 & 2.0093 & 2.3163 & 0.0291 & 2.1629 & 2.1439 & 0.0353 \\
\hline October & 1.7729 & 2.0780 & 0.0393 & 2.1314 & 2.1950 & 0.0222 & 2.1143 & 2.0224 & 0.0353 & 1.8692 & 2.0347 & 0.0367 & 2.2758 & 1.8371 & 0.0390 \\
\hline November & 1.7828 & 2.1033 & 0.0341 & 2.2821 & 1.9283 & 0.0297 & 2.3329 & 2.1829 & 0.0259 & 2.2285 & 1.7290 & 0.0391 & 2.1381 & 1.8864 & 0.0371 \\
\hline December & 1.9091 & 2.4441 & 0.0339 & 1.8086 & 2.2769 & 0.0437 & 1.8765 & 2.2167 & 0.0413 & 2.1275 & 2.2904 & 0.0321 & 1.9591 & 1.7732 & 0.0347 \\
\hline Yearly & 1.8535 & 2.4775 & 0.0204 & 2.0053 & 2.3580 & 0.0203 & 1.8976 & 2.4743 & 0.0263 & 1.9156 & 2.3089 & 0.0268 & 2.0466 & 2.1061 & 0.0284 \\
\hline
\end{tabular}

Wind data, consisting of hourly wind speed records over a 5-year period, 2010-2014, were measured in the Turkish State Meteorological Service in Bilecik. In Bilecik region by using wind speed measured for 4 years between 2010 and 2014, the conformity of wind speed blowing hours with Weibull function has been examined. Distribution of Wind speed is shown by Weibull functions. Scale and shape parameters are calculated $1.8535,2.0053,1.8976,1.9156,2.0466$ and $2.4775,2.3580$, $2.4743,2.3089,2.1061(\mathrm{~m} / \mathrm{s})$ for years, respectively.

Table 1 shows scale and shape parameters for each months of five years and error values.

Other values of 2013 and 2014 years are illustrated in Table 2. $\sigma$ is standard deviation of wind speed in formula (11). Other formulas of wind speed parameters were given in section 2.

$\sigma=\sqrt{c^{2}\left[\Gamma\left(1+\frac{2}{k}\right)-\Gamma^{2}\left(1+\frac{2}{k}\right)\right]}$

Probability density and cumulative probability density functions of wind speed are illustrated in Figure 2 and 3, respectively for 2010-2014 years.

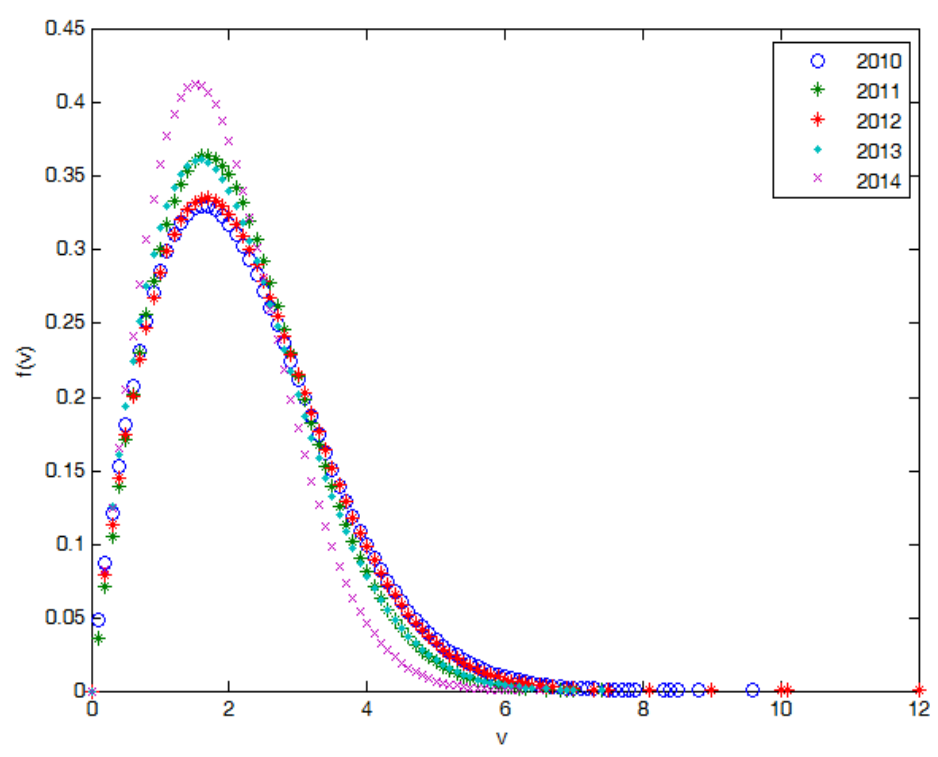

Fig.2. Probability density functions of Weibull distributions 
TABLE II

WIND VALUES AND POWER DENSITY

\begin{tabular}{|c|c|c|c|c|c|c|c|c|c|c|}
\hline \multirow[b]{2}{*}{ Months } & \multicolumn{5}{|c|}{2013} & \multicolumn{4}{|c|}{2014} & \multirow[b]{2}{*}{$\mathbf{P}_{\mathrm{w}}$} \\
\hline & $\mathbf{v}_{\mathbf{m}}$ & $\sigma$ & $\mathbf{V}_{\bmod }$ & $\mathbf{V}_{\text {maks }}$ & $\mathbf{P}_{\mathrm{w}}$ & $\mathbf{v}_{\mathbf{m}}$ & $\sigma$ & $\mathbf{V}_{\text {mod }}$ & $\mathbf{V}_{\text {maks }}$ & \\
\hline January & 2.2018 & 1.0396 & 1.9091 & 3.3053 & 10.31 & 1.8195 & 0.8772 & 1.5544 & 2.7639 & 5.93 \\
\hline February & 2.0294 & 1.0051 & 1.6980 & 3.1320 & 8.46 & 1.6365 & 0.8778 & 1.2724 & 2.6559 & 4.84 \\
\hline March & 1.1094 & 0.5615 & 0.9115 & 1.7348 & 1.41 & 1.9186 & 0.8934 & 1.6791 & 2.8582 & 6.73 \\
\hline April & 2.0671 & 0.9490 & 1.8256 & 3.0557 & 8.31 & 1.8265 & 0.9445 & 1.4723 & 2.8948 & 6.46 \\
\hline May & 2.0842 & 1.1225 & 1.6167 & 3.3876 & 10.02 & 1.9368 & 1.0050 & 1.8425 & 3.1246 & 8.50 \\
\hline June & 2.3448 & 1.2577 & 1.8230 & 3.8054 & 14.24 & 2.0486 & 1.0076 & 1.7236 & 3.1487 & 8.64 \\
\hline July & 2.7986 & 1.2625 & 2.4983 & 4.0986 & 20.31 & 2.2514 & 1.0652 & 1.9494 & 3.3837 & 11.04 \\
\hline August & 2.5287 & 1.2497 & 2.1194 & 3.8976 & 16.34 & 2.2180 & 1.1546 & 1.7768 & 3.5300 & 11.65 \\
\hline September & 2.0526 & 1.0685 & 1.6443 & 3.2668 & 9.23 & 1.8987 & 0.9250 & 1.6092 & 2.9019 & 6.81 \\
\hline October & 1.8065 & 1.0037 & 1.3508 & 3.0029 & 6.79 & 1.6273 & 0.7575 & 1.4246 & 2.4237 & 4.10 \\
\hline November & 1.5313 & 0.7263 & 1.3235 & 2.3047 & 3.48 & 1.6706 & 0.8224 & 1.4046 & 2.5690 & 4.69 \\
\hline December & 2.0285 & 1.0030 & 1.6994 & 3.1275 & 8.43 & 1.5722 & 0.8373 & 1.2315 & 2.5394 & 4.25 \\
\hline Yearly & 2.0483 & 1.1131 & 1.5705 & 3.3535 & 9.63 & 1.8658 & 0.9553 & 1.5177 & 2.9396 & 6.81 \\
\hline
\end{tabular}

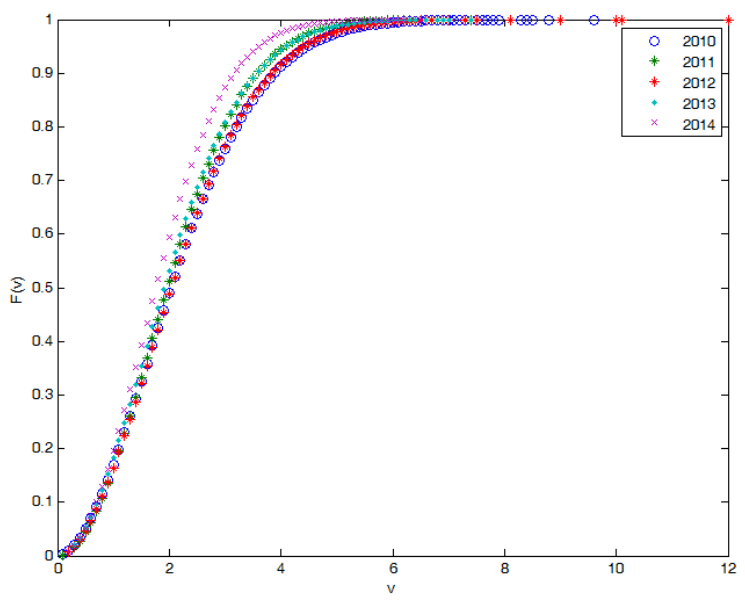

Fig.3. Cumulative probability density function

\section{CONCluSIONS}

It is necessary to establish determine wind speed distribution for establishing a region of wind energy potential. Wind power density distribution is determined according to the definition of wind speed.

The wind energy potential in Bilecik is statistically analyzed based on wind speed data which measured hourly in 2010-2014.
It is used the Weibull distribution to determine wind energy potential of the region. Determination of Weibull parameters was used maximum likelihood method. Weibul shape parameter, $\mathrm{k}$ and scale parameter, $\mathrm{c}$ are found yearly, $1.8535,2.0053,1.8976,1.9156,2.0466$ and $2.4775,2.3580$, $2.4743,2.3089,2.1061(\mathrm{~m} / \mathrm{s})$, respectively.

The lowest power density is observed in winter and autumn for Bilecik region in 2010-2014. Generally, average wind speed and power density values are high in summer. However average wind speed and power density is not only important but also data distribution is significant for energy production.

The studies should continue and the measurements should be done in different regions and at different heights and for long periods of time. The whole region should be examined thoroughly, the characteristics of the region should be identified and cost analysis should be carried out. As a result it is possible to make more accurate and true assessments. Our work about identification and evaluation of renewable energy potential of this region will be continued.

Such studies which are determined to speed up the use of these energy sources and its production in our country is very important for our future. 


\section{ACKNOWLEDGMENT}

The study is selected from National Engineering Research Symposium 2015 (Ulusal Mühendislik Araştırmaları Sempozyumu) UMAS 2015 (Duzce University).

\section{REFERENCES}

[1] Kurban, M., Kantar, Y. M., \& Hocaoğlu, F. O. (2006). Rüzgar Enerjisi Potansiyelinin Araştırılmasında Werbull Ve Rayleıgh Dağılımının Kullanılması. Sakarya Üniversitesi Fen Bilimleri Enstitüsü Dergisi, 10(1), 14-21.

[2] Kurban, M., Hocaoğlu, F. O., \& Kantar, Y. M. (2011). Rüzgar Enerjisi Potansiyelinin Tahmininde Kullanılan İki Farklı İstatistiksel Dağılımın Karşılaștırmalı Analizi. Pamukkale University Journal Of Engineering Sciences, 13(1).

[3] Akdağ, S. A., \& Güler, Ö. (2008) Weibull Dağılım Parametrelerini Belirleme Metodlarının Karşılaştırılması. VII. Ulusal Temiz Enerji Sempozyumu, UTES'2008 17-19 Aralık 2008, İstanbul,707-714.

[4] Genc, A., Erisoglu, M., Pekgor, A., Oturanc, G., Hepbasli, A., \& Ulgen, K. (2005). Estimation of wind power potential using Weibull distribution. Energy Sources, 27(9), 809-822.

[5] Yıldırım, U., Gazibey, Y., \& Güngör, A. (2012). Niğde İli Rüzgar Enerjisi Potansiyeli. Mühendislik Bilimleri Dergisi, 1(2), 37-47.

[6] Akdağ, S. A., \& Dinler, A. (2009). A New Method To Estimate Weibull Parameters For Wind Energy Applications. Energy Conversion And Management, 50(7), 1761-1766.

[7] Cheng, R. C. H., \& Amin, N. A. K. (1983). Estimating parameters in continuous univariate distributions with a shifted origin. Journal of the Royal Statistical Society. Series B (Methodological), 394403 .

[8] Patel, M. R. (2005). Wind and solar power systems: design, analysis, and operation. CRC press.

[9] Stevens, M. J. M., \& Smulders, P. T. (1979). The estimation of the parameters of the Weibull wind speed distribution for wind energy utilization purposes. Wind engineering, 3, 132-145

\section{BIOGRAPHIES}

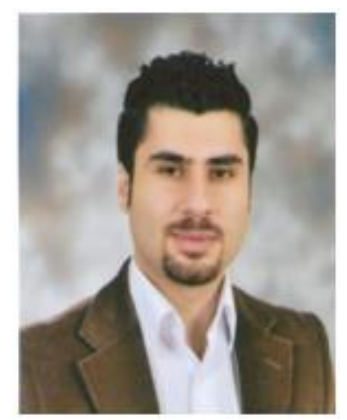

Emrah DOKUR was born in Istanbul, Turkey in 1987. He received the B.Sc. in Electrical and Electronics Engineering from Faculty of Engineering, Istanbul University, Turkey in 2010 and M.Sc. degrees in Electrical Engineering, Istanbul Technical University, Turkey in 2013. He is a Ph.D. student Department of Energy System Engineering in Bilecik S.E. University. Since 2011, he has been research assistance in the same university. His research areas include high voltage engineering, renewable energy systems, power system analysis.

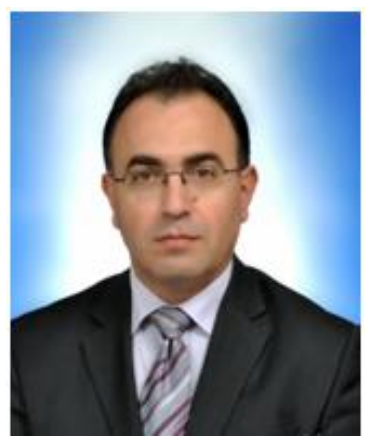

Mehmet KURBAN was born in Istanbul, Turkey. He graduated from Istanbul Technical University (ITU) in Turkey as an Electrical Engineer from Faculty of Electrical and Electronics Engineering in 1991. He got M. Sc. and $\mathrm{Ph}$. D degree from ITU in 1994 and 2001 , respectively. Since 2011, he has been professor in the same Bilecik S.E. University. His special fields of interest included renewable energy, power system cost analysis and optimization. 